\title{
Ethnobotanical study of medicinal plants used by local communities in Sekerak Subdistrict, Aceh Tamiang, Indonesia
}

\author{
ZIDNI ILMAN NAVIA ${ }^{1, \boldsymbol{v}}$, ADI BEJO SUWARDI ${ }^{2}$, BAIHAQI ${ }^{3}$ \\ ${ }^{1}$ Department of Biology, Faculty of Engineering, Universitas Samudra. Jl. Meurandeh, Langsa 24416, Aceh, Indonesia. \\ Tel.: +62-641-426535, `email: navia1529@gmail.com. \\ ${ }^{2}$ Department of Biology Education, Faculty of Teacher Training and Education, Universitas Samudra. J1. Meurandeh, Langsa 24416, Aceh, Indonesia \\ ${ }^{3}$ Department of English Language Education, Faculty of Teacher Training and Education, Universitas Samudra. Jl. Meurandeh, Langsa 24416, Aceh, \\ Indonesia
}

Manuscript received: 1 September 2021. Revision accepted: 21 September 2021.

\begin{abstract}
Navia ZI, Suwardi AB, Baihaqi. 2021. Ethnobotanical study of medicinal plants used by local communities in Sekerak Subdistrict, Aceh Tamiang, Indonesia. Biodiversitas 22: 4273-4281. Local communities in Aceh Tamiang have gained a wealth of medicinal knowledge through practice and experience in their long-term battles with the disease. However, because of a lack of written records and rapid economic development, their traditional medicinal knowledge is under threat. This study investigated medicinal plants and related traditional knowledge of local communities in the Sekerak subdistrict, Aceh Taming District, Indonesia. Field surveys, plant collections, and interviews with communities were used in this study. The Snowball Sampling technique was used to select 60 informants for the interviews. A total of 46 medicinal plant species belonging to 40 genera and 26 families were used for medicinal purposes by local communities to treat 28 different diseases. The itch, swelling, cough, and nosebleed were the most commonly treated. With a use-value index of 0.98 , Tagetes erecta was the most commonly used medicinal plant by local communities. In addition, local communities identified the leaf (50\%) as the most widely used plant part and oral administration (65\%) as the most common method of administering traditional medicine. Elders have more knowledge of medicinal plants than younger generations, indicating that traditional knowledge is eroding across generations. However, initiatives to promote and conserve medicinal plants must be improved, particularly among the younger generation. This is required to ensure the availability of medicinal plants and the preservation of traditional knowledge in the future.
\end{abstract}

Keywords: Aceh, biodiversity, medicine, Sekerak, traditional knowledge

\section{INTRODUCTION}

Most of the peoples around the world have used such medicinal plants to treat different types of diseases since ancient times (Qureshi et al. 2016). Currently, medicinal plants continue to capture the interest of modern medicine, particularly the pharmaceutical sector in the discovery of better drugs (Rivera et al. 2005). It is estimated that approximately $80 \%$ of the global population uses phytotherapy (Miraldi and Baini 2018). For centuries, medicinal plants have been used in rural areas and widely in urban areas in both developing and developed countries (Kidane et al. 2018; Hu et al. 2020; Elfrida et al. 2021; Pathy et al. 2021). According to the World Health Organization (WHO), herbal medicine is used by approximately $80 \%$ of the worldwide population for the health care system, particularly in rural areas (Hu et al. 2020). Leading to a lack of modern health facilities in developing countries, traditional medicines, therefore, provide an inexpensive source of primary health care (Aziz et al. 2018).

Medicinal plant use and the accumulated knowledge of traditional pharmacological practices are a rich cultural heritage that is an integral part of local traditions and culture, and they should be protected to ensure their longterm use. Several studies have addressed traditional knowledge and skills in medicinal plant use being lost or at risk of extinction (Pathy et al. 2021). They have identified the most important causes of medicinal plant species extinction as degradation, destruction of natural habitat, and young people's lack of enthusiasm in traditional culture as a result of westernization, acculturation, and education (Yineger et al. 2008).

Over a long history, local communities in the Aceh Tamiang District, along with almost $80 \%$ of whom live in rural areas, have accumulated a wealth of folk medicinal knowledge and represented many experiences in treating common local diseases. Although the use of medicinal plants in Indonesia has been studied in different locations, particularly in Aceh province (Elfrida et al. 2020; Navia et al. 2020; Sutrisno et al. 2020; Suwardi et al. 2020; Navia et al. 2021), it was discovered that many of them were poorly described and neglected. In addition, traditional medicinal knowledge is threatened by a lack of written records and conservative inheritance behavior. Several studies have found that many young people worldwide are uninterested in traditional medical knowledge (Yineger et al. 2008; Merétika et al. 2010; Ianni et al. 2015; Bruschi et al. 2019; Weckmüller et al. 2019; Suwardi et al. 2021). As a result, study and documentation of medicinal plants and the associated indigenous knowledge are required. This study investigated medicinal plants and related traditional 
knowledge of local communities in the Sekerak subdistrict, Aceh Taming, Indonesia.

\section{MATERIALS AND METHODS}

\section{Study area}

The study was conducted from May to August 2021 at Sekerak Subdistrict, Aceh Tamiang District, Aceh Province, Indonesia. The study area is in the Sekerak Kanan, Bandar Mahligai, and Lubuk Sidup villages (Figure 1). The Sekerak subdistrict is administratively part of the Aceh Tamiang district. This area is located at $04^{\circ} 15^{\prime} 31.00^{\prime \prime}$ - 04²3'39.00" N; 97²6'32.00" - 9806'19.00" E; 200-500 $\mathrm{m}$ asl. The district has an area of $257.95 \mathrm{~km} 2$ with 7001 people consisting of 3517 men and 3484 women. Climatic conditions in the Sekerak subdistrict are tropical humid, and monthly temperature ranges from 26 to $30^{\circ} \mathrm{C}$. Most people depend on agriculture, with rice, rubber, and oil palm as the primary product (Central Bureau of Statistics of Aceh Tamiang District 2021).

\section{Data collection}

A total of 60 respondents were selected using the snowball method (Pathy et al. 2021) and surveyed using semi-structured interviews (Table 1). The respondents were local inhabitants aged between 15 and 68 years old. Interviews and discussions were performed based on a checklist of questions prepared in Indonesian. Before each interview, prior informed consent was requested, and during the interview process, we followed international codes of ethics (International Society of Ethnobiology 2006). The local names of the plants, the disease treated by the plants, the plant parts used, the modes of preparation, and the routes of administration were carefully recorded during the interviews with the respondents.

Field observations were performed to identify the morphological features and habitats of each medicinal plant species. Voucher specimens of the local medicinal plants were collected from the home gardens. They were identified in the Laboratory of Biology, Samudra University, and confirmed according to botanical websites (http://www.plantsoftheworldonline.org/). For this study, voucher specimens were not deposited in the herbarium.

\section{Data analysis}

Use Value (UV)

Relative importance attached to a given medicinal plant species was calculated using UVs (medicinal use-value) parameter used by Evert et al. (2009):

$$
U V s=\frac{\sum_{i=1}^{n} U i s}{n s}
$$

Where: UVs is the use-value of a given species s; $\mathrm{U}$ is the number of uses of species s mentioned by respondent $\mathrm{i}$; $n s$ is the total number of respondents.

Table 1. The demographic structure of respondents

\begin{tabular}{llcc}
\hline Parameter & Specification & Freq. & Percentage \\
\hline Gender & Male & 21 & 35.0 \\
Age & Female & 39 & 65.0 \\
& $15-25$ & 14 & 23.3 \\
& $26-35$ & 11 & 18.3 \\
& $36-45$ & 7 & 11.7 \\
\multirow{5}{*}{ Education } & $46-55$ & 15 & 25.0 \\
& $56-65$ & 5 & 8.3 \\
& $>65$ & 7 & 11.7 \\
& None & 17 & 28.3 \\
& Elementary School & 12 & 20.0 \\
& Junior High School & 11 & 18.3 \\
\multirow{5}{*}{ Marital status } & Senior High School & 12 & 20.0 \\
& University & 8 & 13.3 \\
& Single & 14 & 23.3 \\
& Marriage & 38 & 63.3 \\
& Widow & 8 & 13.3 \\
\hline
\end{tabular}

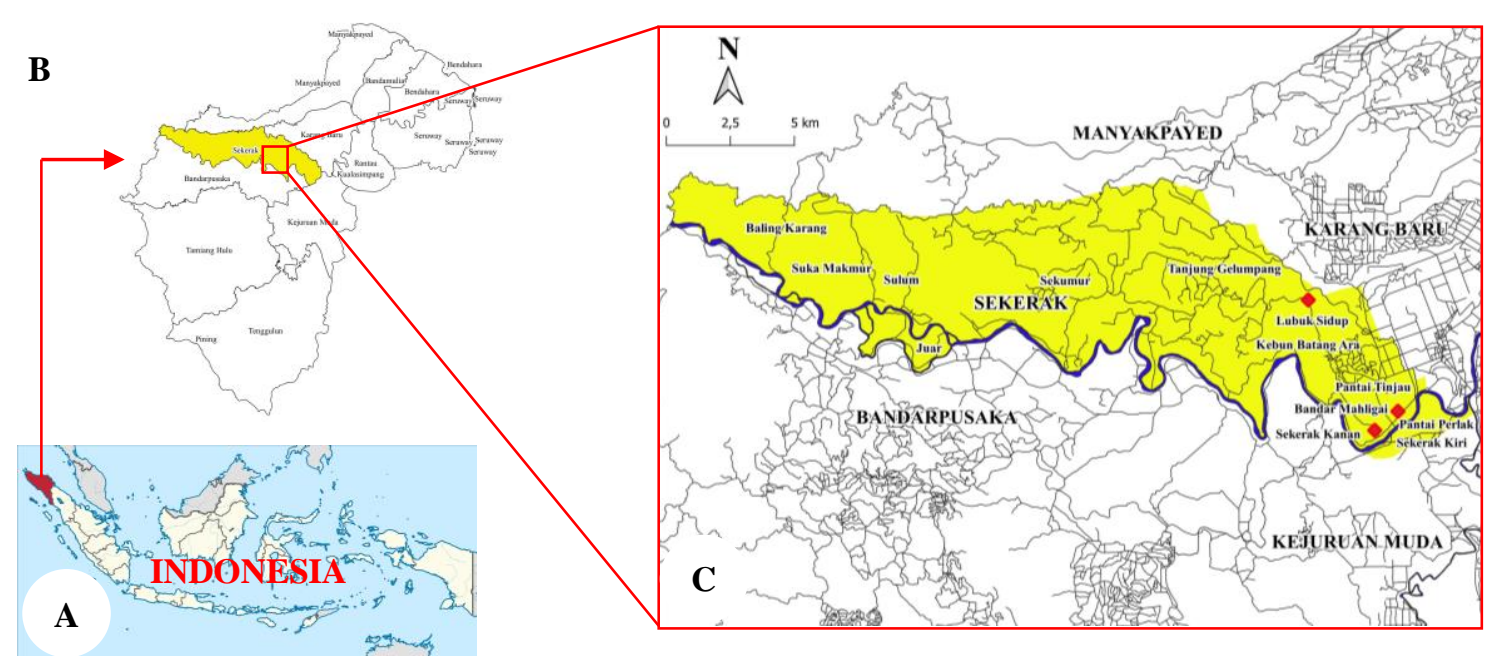

Figure 1. Shows the site of the studied area. A. The map is showing the location of Aceh province, Indonesia, its neighboring provinces, B. The map is showing the location of Aceh Tamiang District, C. The map is highlighting the Sekerak subdistrict, and $(\diamond)$ showing the site of the study 


\section{Informant Agreement Ratio (IAR)}

The Informant Agreement Ratio (IAR) was calculated following Nzuki et al. (2013):

$$
I A R=\frac{N r-N a}{N r-1}
$$

Where: $\mathrm{Nr}$ is the total number of citations of the species and $\mathrm{Na}$ is the number of diseases treated by the species.

\section{Informant Consensus Factor (ICF)}

The informant consensus factor (ICF) was calculated to determine the effectiveness of the medicinal plants in each disease category according to Heinrich et al. (1998):

$$
I C F=\frac{N u r-N t}{N u r-1}
$$

Where: Nur is the number of individual reports of the plant used for a particular illness category and $\mathrm{Nt}$ is the total number of species used by all respondents for this illness category.

\section{Fidelity Level (FL)}

The fidelity level (FL) was calculated for each preferred species for their popularity according to the respondents who cited them in the treatment of a particular disease. The formula is provided below (Ugulu 2010):

$$
F L=\frac{I_{p}}{I_{u}} \times 100
$$

Where: $I_{\mathrm{p}}$ is the number of informants who suggested the use of a species for the same major purpose (therapeutic use) and $I_{\mathrm{u}}$ is the total number of respondents who mentioned the plant species for any use.

\section{RESULTS AND DISCUSSION}

\section{Diversity of medicinal plants}

From the study sites, 46 medicinal plant species belonging to 40 genera and 26 families were documented. Ethnomedicinal information for each species, including its family name, scientific name, vernacular name, growth form, plant parts used, preparation, application methods, and disease, are listed in Table 2.

Among the families that contributed more medicinal species were Zingiberaceae, represented by 6 species, followed by Rutaceae with 4 species, Euphorbiaceae, Piperaceae, and Rubiaceae with 3 species in each family, and the remaining families each with one or two species. Zingiberaceae is the dominant family found in the study area, which is consistent with reported of Jadid et al. (2020) in Ngadisari village, East Java. The use of the same plant species in different locations may be due to their cosmopolitan distribution, serve a specific purpose, or be attributed to traditional knowledge being a closely guarded secret (Tugume and Nyakoojo 2019).

\section{Growth form and plant parts used}

The results of growth form analysis revealed that shrub plants represent the highest proportion (16 species), followed by the tree (14 species), herbaceous (12 species), a climber (4 species), and shrub (1 species) (Figure 2).

The abundance of shrubs in the study area could explain the high usage of shrubs. These findings contradict Ani et al. (2021), who discovered that trees were the dominant species for herbal medicine in Ndano village, West Nusa Tenggara. According to respondents, shrubs are grown in home gardens due to their small size, and in addition to being medicinal plants, several species are used as food and ornamental plants. Plants are grown in home gardens in rural areas for various purposes, including food, medicine, ornamental plants, traditional ceremonies, and family income (Elfrida et al. 2020; Suwardi et al. 2020b; Sutrisno et al. 2021). The fact that cultivated plants are rich in bioactive compounds explains the high frequency of occurrence of medicinal plant species in home gardens. Harvesting from home gardens was stimulated by the need to have medicinal plant species close to residents to avoid long distances in their exploration of medicinal plant species in the wild (Tugume and Nyakoojo 2019).

Local communities in the study area use different plant parts to prepare traditional medicine (e.g., latex, leaf, stem, root, seed, bark, flower, and fruit) (Figure 3).

Leaf $(50 \%)$ were the most commonly used plant part as an ethnomedicinal practice of the communities in the study area. This study is consistent with the studies reported by Tantengco et al. (2018) and Suwardi et al. (2021) that local communities have the most used leaves in ethnomedicinal practices compared to other parts of the plant. The leaves have been widely used in traditional medicine due to the presence of bioactive compounds other than parts of the plant (Ismail and Wan Ahmad 2019). During the fieldwork, respondents mentioned that leaves are also easy to gather and are the most abundant part of the plant. Furthermore, the use of plant parts as traditional medicine can offer protection and ensure the plant's long-term viability. Leaves are considered to synthesize a wide variety of secondary metabolites, including alkaloids, saponins, and phenolic compounds (Tantengco et al. 2018) that could be concerned for the pharmacological effects encountered by the local communities. Several plants are used as traditional medicine, such as Annona muricata, which is known to have diterpenoids, flavonoids, polyphenols, saponins, alkaloids, kaempferol, and acetogenin, which is antimalarial activity (Endale et al. 2013; Pimenta et al. 2014; Somsak et al. 2016). The application of $A$. muricata aqueous leaf extract in the treatment of malaria is known to have no toxic effect (Somsak et al. 2016).

\section{Preparation and application methods}

There are numerous different ways to prepare medicinal plants to treat human diseases. In the study area, the most common methods of preparation of traditional medicines from plant material were decoction (61\%), followed by crushed (9\%), and infusion (7\%) (Figure 4). 
Table 2. Taxonomic diversity of medicinal plants in the study area

\begin{tabular}{|c|c|c|c|c|c|c|c|}
\hline Family name & Scientific name & Vernacular name & $\begin{array}{l}\text { Growth } \\
\text { form }\end{array}$ & $\begin{array}{l}\text { Parts } \\
\text { used }\end{array}$ & Preparation & $\begin{array}{l}\text { Application } \\
\text { methods }\end{array}$ & Disease \\
\hline Acanthaceae & Ruellia simplex C.Wright & Kencana biru & $\mathrm{S}$ & Le & Decoction & Oral & Diabetes \\
\hline \multirow[t]{2}{*}{ Annonaceae } & Annona muricata $\mathrm{L}$. & Daun sirsak & $\mathrm{T}$ & $\mathrm{Le}$ & Decoction & Oral & $\begin{array}{l}\text { Breast cancer, fever, malaria, } \\
\text { hypertension, wound, breast cancer }\end{array}$ \\
\hline & Annona squamosa $\mathrm{L}$. & Srikaya & $\mathrm{T}$ & $\mathrm{Le} / \mathrm{Fr}$ & Raw state, decoction & Oral & $\begin{array}{l}\text { Hypertension, stomachache, breast } \\
\text { cancer }\end{array}$ \\
\hline \multirow[t]{2}{*}{ Asteraceae } & Tagetes erecta $\mathrm{L}$. & Tahi ayam & S & $\mathrm{Le} / \mathrm{Fr}$ & Crushed, decoction & Oral & Cough, indigestion, cold, diarrhea \\
\hline & Ageratum conyzoides $\mathrm{L}$. & Bandotan & $\mathrm{H}$ & $\mathrm{Le}$ & Crushed & Friction & Itch \\
\hline Brassicaceae & Raphanus raphanistrum L. & Lobak & $\mathrm{H}$ & $\mathrm{Fr}$ & Infusion & Oral & Gout arthritis \\
\hline Bromeliaceae & Ananas comosus (L.) Merr. & Nenas & $\mathrm{H}$ & Fr & Infusion & Oral & Gout arthritis \\
\hline Campanulaceae & Hippobroma longiflora (L.) G.Don & Bunga katarak & $\mathrm{H}$ & Fw & Infusion & Dropping & Cataract \\
\hline \multirow[t]{3}{*}{ Euphorbiaceae } & Aleurites moluccanus (L.) Willd. & Kemiri & $\mathrm{T}$ & Fr & Decoction & Gargle & Toothache \\
\hline & Jatropha curcas L. & Daun jarak & $\mathrm{S}$ & Fr & Decoction & Oral, gargle & Indigestion, sprue, toothache \\
\hline & Jatropha multifida $\mathrm{L}$. & Daun betadine & $S$ & $\mathrm{Lt}$ & Extracted & Smearing & Skin burn, sprue \\
\hline \multirow[t]{2}{*}{ Fabaceae } & Archidendron pauciflorum (Benth.) I.C. Nielsen & Jengkol & $\mathrm{T}$ & Ro & Decoction & Oral & Diabetes \\
\hline & Senna acanthoclada (Griseb.) H.S.Irwin \& Barneby & Gelinggang & S & $\mathrm{Le}$ & Crushed & Friction & Ringworm \\
\hline \multirow[t]{2}{*}{ Lamiaceae } & Orthosiphon aristatus (Blume) Miq & Kumis kucing & S & $\mathrm{Le}$ & Decoction & Oral & Constipation \\
\hline & Peronema canescens Jack & Sungkai & $\mathrm{T}$ & $\mathrm{Le}$ & Decoction & Oral & Hypertension \\
\hline Liliaceae & Aloe vera (L.) Burm.f. & Lidah buaya & $\mathrm{H}$ & $\mathrm{Lt} / \mathrm{Le}$ & Extracted, crushed & Oral, smearing & Laxative, aging, alopecia \\
\hline Malvaceae & Hibiscus rosa-sinensis $\mathrm{L}$. & Kembang sepatu & $\mathrm{S}$ & Le & Decoction & Oral & Fever \\
\hline Marantaceae & Donax canniformis (G.Forst.) K. Schum & Bamban & $\mathrm{S}$ & $\mathrm{Se}$ & Decoction & Dropping & Eye inflammation \\
\hline Melastomataceae & Melastoma malabathricum L. & Senggani & $S$ & $\mathrm{Le}$ & Crushed, decoction & $\begin{array}{l}\text { Friction, } \\
\text { smearing oral }\end{array}$ & Itch, diabetes, wound \\
\hline \multirow[t]{2}{*}{ Meliaceae } & Aglaia odorata Lour & Pacar cina & S & $\mathrm{Le}$ & Decoction & Oral & Menstrual pain, fever, insomnia \\
\hline & Lansium domesticum Corrêa & Langsat & $\mathrm{T}$ & $\mathrm{Ba}$ & Decoction & Oral & Malaria \\
\hline Moraceae & Artocarpus heterophyllus Lam. & Putik nangka & $\mathrm{T}$ & $\mathrm{Le} / \mathrm{S}$ & Raw state, decoction & $\begin{array}{l}\text { Oral, dropping, } \\
\text { smearing }\end{array}$ & $\begin{array}{l}\text { Fever, swelling, wounds, skin } \\
\text { diseases, diarrhea }\end{array}$ \\
\hline \multirow[t]{2}{*}{ Myrtaceae } & Psidium guajava $\mathrm{L}$. & Jambu biji/batu & $\mathrm{T}$ & Le & Decoction & Gargle, oral & Sprue, diarrhea, wound \\
\hline & Syzygium polyanthum (Wight.) Walp. & Daun salam & $\mathrm{T}$ & Le & Crushed, decoction & Friction, oral & $\begin{array}{l}\text { Indigestion, gout arthritis, } \\
\text { hypertension, cholesterol }\end{array}$ \\
\hline Pandanaceae & Pandanus amaryllifolius Roxb. & Pandan & $\mathrm{S}$ & $\mathrm{Le}$ & Decoction & Friction & Indigestion, stomachache \\
\hline \multirow[t]{3}{*}{ Piperaceae } & Peperomia pellucida (L.) Kunth & Sirih cina & $\mathrm{C}$ & $\mathrm{Le}$ & Crushed & Friction & Gout arthritis \\
\hline & Piper betle L. & Sirih & $\mathrm{C}$ & Le & Decoction & Dropping, oral & Nose bleeding, fever \\
\hline & Piper ornatum N.E.Br. & Sirih merah & $\mathrm{C}$ & $\mathrm{Le}$ & Decoction & Oral & Diabetes \\
\hline Poaceae & Cymbopogon citratus (D.C) Stapf & Serai & $\mathrm{H}$ & St & Crushed, decoction & Friction, oral & Indigestion, stomachache \\
\hline Podocarpaceae & Podocarpus acuminatus de Laub. & Melur & $\mathrm{T}$ & $\mathrm{Le}$ & Decoction & Oral & Fever \\
\hline Polygonaceae & Antigonon leptopus Hook. \& Arn. & Air mata pengantin & $\mathrm{C}$ & $\mathrm{Le} / \mathrm{Fw}$ & Decoction & Oral & Diabetes \\
\hline
\end{tabular}




\begin{tabular}{|c|c|c|c|c|c|c|c|}
\hline Rhamnaceae & Ziziphus mauritiana Lam. & Daun bidara & $\mathrm{T}$ & Le & Decoction & Oral & Diabetes, cholesterol \\
\hline \multirow[t]{3}{*}{ Rubiaceae } & Coffea abbayesii J.-F.Leroy & Kopi & $\mathrm{T}$ & Le & Decoction & Oral & Cholesterol \\
\hline & Mitragyna speciosa (Korth.) Havil & Daun biak & S & $\mathrm{Le}$ & Maceration & Oral & Cholesterol, hypertension \\
\hline & Morinda citrifolia $\mathrm{L}$. & Daun kudu & $\mathrm{T}$ & $\mathrm{Le} / \mathrm{Fr}$ & Decoction & $\begin{array}{l}\text { Medicinal bath, } \\
\text { oral }\end{array}$ & Fever, hypertension, gout arthritis \\
\hline \multirow[t]{4}{*}{ Rutaceae } & Acronychia laevis J.R.Forst. \& G.Forst. & Daun pacar & $\mathrm{S}$ & $\mathrm{Le}$ & Crushed & Oral & Gastric ulcer, skin burn \\
\hline & Citrus x aurantiifolia (Christm.) Swingle & Jeruk nipis & $\mathrm{S}$ & $\mathrm{Fr}$ & Squeezed & Oral & Sprue, cough \\
\hline & Citrus limon (L.) Osbeck & Lemon & $\mathrm{S}$ & $\mathrm{Fr}$ & Squeezed & Oral & Cough, obesity \\
\hline & Murraya koenigii (L.) Spreng & Temurui & $\mathrm{T}$ & $\mathrm{Le}$ & Decoction & Oral & Cholesterol, hypertension \\
\hline Solanaceae & Capsicum frutescens $\mathrm{L}$. & Cabai & $\mathrm{H}$ & $\mathrm{Le}$ & Decoction & Oral & Alopecia \\
\hline \multirow[t]{6}{*}{ Zingiberaceae } & Alpinia chinensis (Retz.) Roscoe & Sitawa & $\mathrm{S}$ & Le & Decoction & Oral & Fever \\
\hline & Alpinia purpurata (Vieill). K.Schum. & Lengkuas & $\mathrm{H}$ & $\mathrm{Rz} / \mathrm{Le}$ & Decoction & Oral & Menstrual pain, gout arthritis \\
\hline & Curcuma longa $\mathrm{L}$. & Kunyit & $\mathrm{H}$ & $\mathrm{Rz} / \mathrm{Le}$ & Decoction & Oral & Gout arthritis, gastric unclear \\
\hline & Curcuma zedoaria (Christm.) Roscoe & Kunyit putih & $\mathrm{H}$ & $\mathrm{Rz} / \mathrm{Le}$ & Decoction & Oral & Hypertension \\
\hline & Kaempferia galanga $\mathrm{L}$. & Kencur & $\mathrm{H}$ & $\mathrm{Rz} / \mathrm{Le}$ & Decoction & Oral & $\begin{array}{l}\text { Indigestion, stomachache, diarrhea, } \\
\text { fever }\end{array}$ \\
\hline & Zingiber officinale Roscoe & Jahe & $\mathrm{H}$ & $\mathrm{Rz} / \mathrm{Le}$ & Decoction & Oral & Indigestion, stomachache, fever \\
\hline
\end{tabular}

Note: Habit: H: Herbaceous, S: Shrub, T: Tree, P: Palm, C: Climber; Parts used: Ro: Root, Ba: Bark, Lt: Latex, St: Stem, Le: Leaf, Fw: Flower, Fr: Fruit, Se: Seed, Rz: Rhizome. 
Decoction (61\%) was the most common application method for communities in the study area. During the fieldwork, the respondents stated that decoction encourages the absorption of herbal remedies and improves the taste of medicinal plants. The decoction method is considered the major method of preparing herbal remedies and is widely used by other ethnic groups worldwide (Hu et al. 2020; Elfrida et al. 2021; Pathy et al. 2021).

The traditional medicines were used in six main ways, including oral, gargle, friction, dropping, smearing, and bathing (Figure 5). The most common method was oral administration (64\%), followed by friction (9\%).

Oral administration (65\%) was the most popular method of traditional medicine administration. This method was popular since it is a simple administration. It has also been discovered to be widely used in other studies (Bano et al. 2014; Polat et al. 2015; Aziz et al. 2018; Phumthum et al. 2018). Local communities frequently use additives such as honey, salt, and sugar to improve the flavor, taste, and overall acceptability of several oral route remedies. Local communities also use medicinal baths as part of their traditional medicinal practices. In addition to oral administration, respondents indicated that medicinal baths are safe, easy to use, and have no negative side effects when used as an external treatment method. A medicinal bath is typically used to induce sweating, reduce fever, activate blood circulation to dispel blood stasis, expel wind to alleviate excess gas and relieve itching (Yang et al. 2009). Medicinal baths can also be used to treat and prevent diseases (Hu et al. 2020), such as skin problems. The skin is immersed in the medicinal bath water, allowing the bath constituents with medicinal value to be absorbed (Wang et al. 2002). Hot water can also increase blood capillary dilation and metabolism. Medicinal baths have been reported to be widely used by communities in southern and southwestern China (Luo et al. 2018).

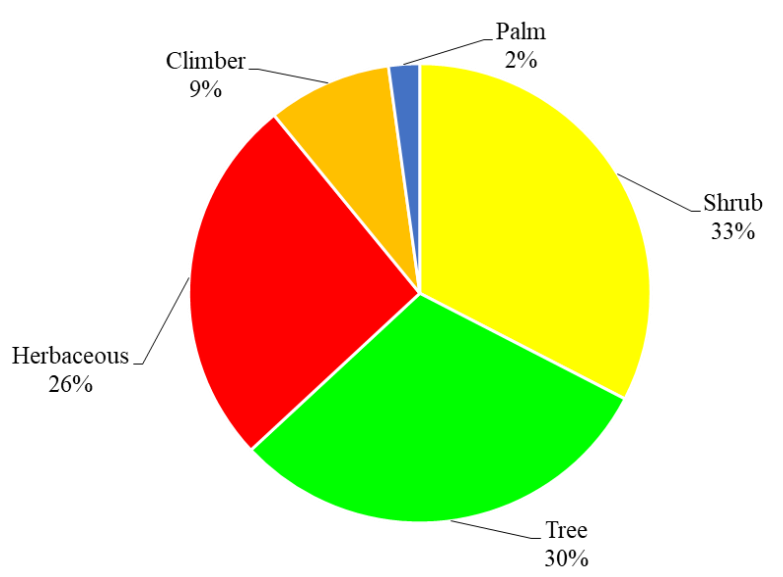

Figure 2. The growth form of medicinal plants in the study area

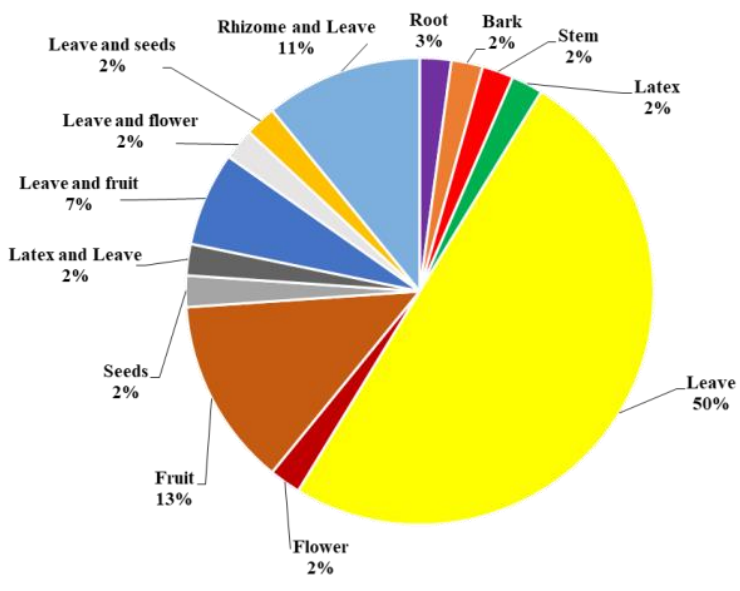

Figure 3. Plant parts used in the treatment of human disease

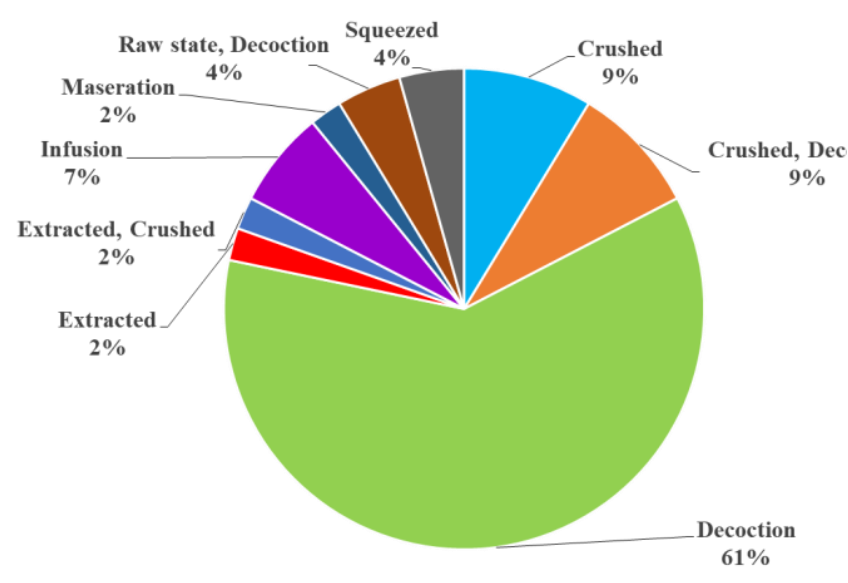

Figure 4. Preparation method of medicinal plants

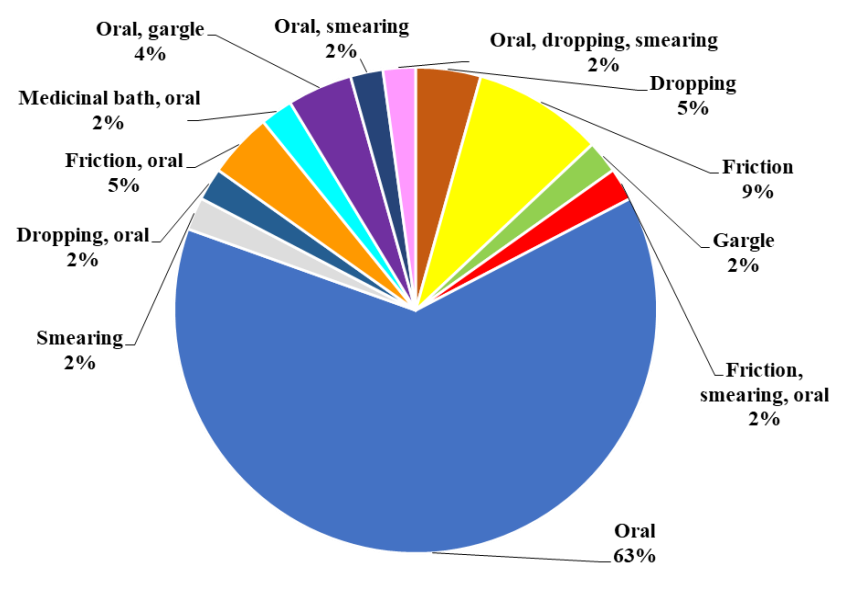

Figure 5. The application method of medicinal plants 
The local importance of medicinal plants

Medicinal plant use-values ranged from 0.03 to 0.98 . Tagetes erecta (0.98), Kaempferia galanga (0.90), Melastoma malabathricum (0.85), Zingiber officinale (0.83), Psidium guajava (0.82), Piper betle (0.80), Morinda citrifolia (0.77), Aloe vera (0.57), Annona muricata (0.55), and Murraya koenigii (0.52) were the most important species in the traditional medicine of local communities, with UVs $>0.50$ (Figure 6). The informant agreement on plant use ranged from 0.8 to 1.0 . Twenty-five $(54.3 \%)$ species had the maximum IAR-value of 1 (Figure 7). These species have the highest level of agreement as a treatment for allergy, toothache, fever, hypertension, stomachache, diabetes, diarrhea, and ulcer.

Diseases reported by respondents have been classified according to the International Classification of Diseases 10 ver. 2019 (https://icd.who.int). A total of 32 diseases in 16 categories were documented in the study area (Table 3 ).

The most common use-report categories were symptoms, signs, and abnormal clinical and laboratory (183 use-report, 11 species), followed by diseases of the digestive system (170 use-reports, 15 species), certain infectious and parasitic diseases (86 use-reports, 6 species), and diseases of the circulatory system (76 use-reports, 7 species). The ICF values ranged from 0.667 to 0.953 . Most of the disease categories had a high ICF value, they were diseases of the skin and subcutaneous tissue and symptoms (0.953), and signs involving the circulatory and respiratory systems (0.953), while the lowest was for Neoplasms (NP) (0.667). Itch, swelling, cough, and nosebleed were specific diseases that have high ICF value. According to respondents, nose bleeding was common in children under the age of two. However, they also stated that nose bleeding was also found in adolescents. Nosebleed (epistaxis) is uncommon before the age of two years, and its prevalence increases with age (Fuller and Prosser 2018), with the majority of cases emerging from low-income families (Said and Mohasseb 2020). The local communities in the study area used Piper betle leave for the treatment of nose bleeding. The leaf is rolled and inserted into the nostrils. The majority of Indonesians, particularly those living in rural areas, use $P$. betle to treat various diseases, such as nose bleeding (Sucipto et al. 2016). P. betle is wellknown for its biologically active compounds, which include alkaloids, saponins, flavonoids, polyphenols, and essential oil, and it has been shown to have a significant wound healing effect (Shah et al. 2016).

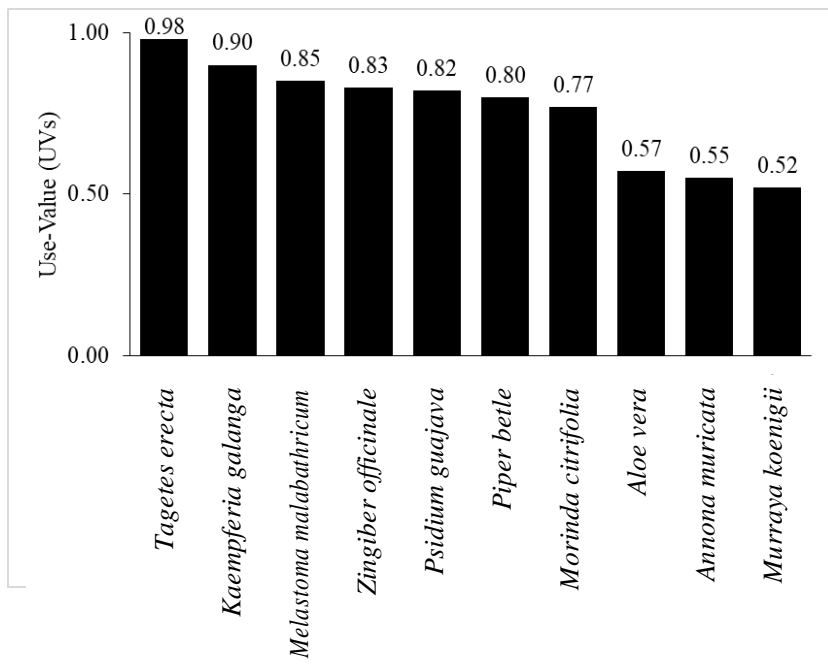

Figure 6. Ranking of most important medicinal plant species according to UV (Use Value)

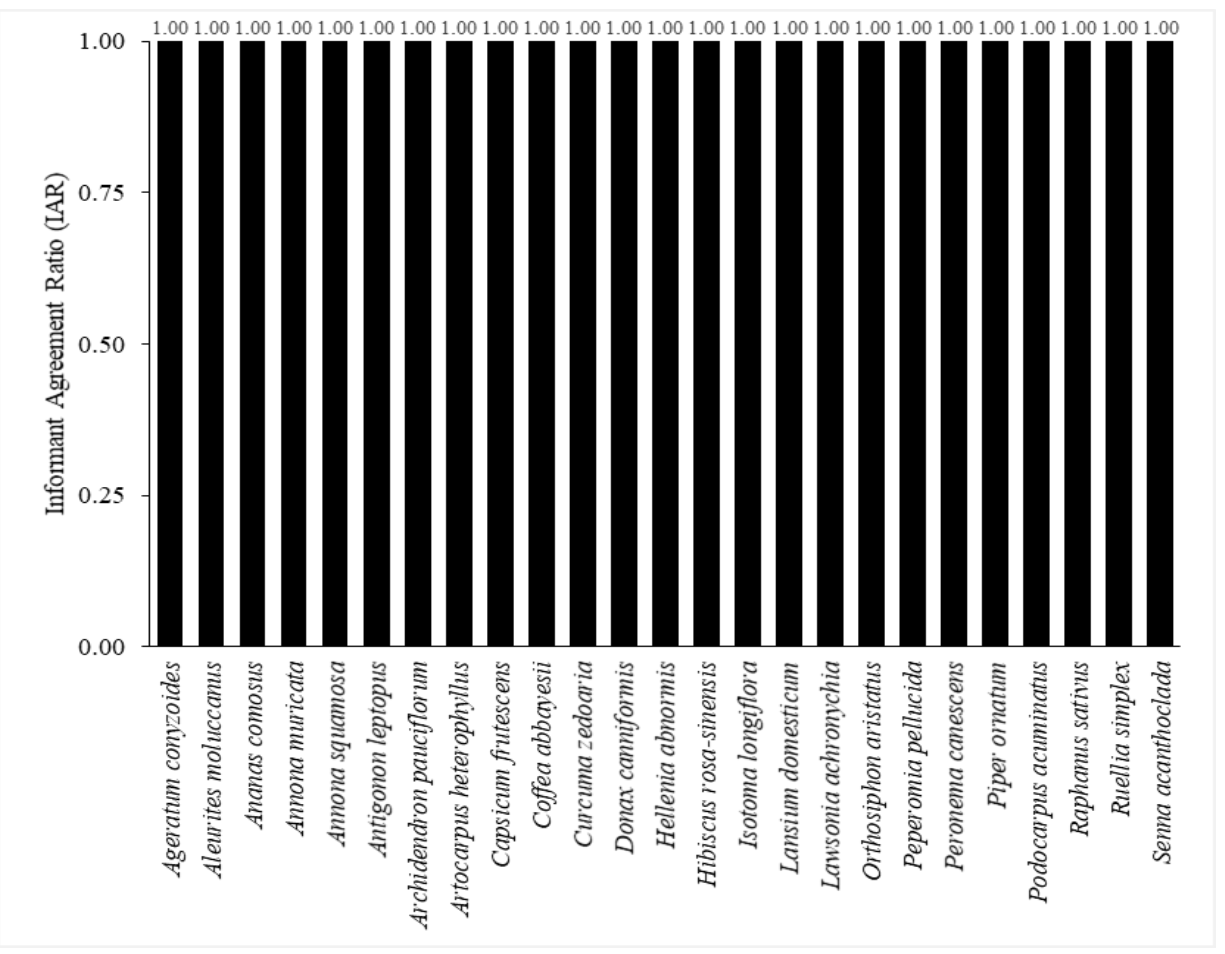

Figure 7. Ranking of most important medicinal plant species according to IAR (Informant Agreement Ratio) 
Table 3. Informant consensus factor by categories of diseases

\begin{tabular}{|c|c|c|c|c|}
\hline Classification of diseases & Specific disease name & $\begin{array}{c}\text { Number } \\
\text { use-report }\end{array}$ & $\begin{array}{c}\text { Number } \\
\text { species }\end{array}$ & $\begin{array}{l}\text { ICF } \\
\text { value }\end{array}$ \\
\hline Certain infectious and parasitic diseases (CID) & Diarrhea, ringworm, malaria & 86 & 6 & 0.941 \\
\hline Diseases of the circulatory system (CSD) & Hypertension & 76 & 7 & 0.920 \\
\hline Diseases of the digestive system (DSD) & $\begin{array}{l}\text { Constipation, gastric ulcer, } \\
\text { stomachache, toothache, } \\
\text { indigestion, cholesterol }\end{array}$ & 170 & 15 & 0.917 \\
\hline Diseases of the eye and adnexa (EAD) & Eye inflammation, cataract & 8 & 2 & 0.857 \\
\hline Diseases of the genitourinary system (GD) & Menstrual pain & 15 & 2 & 0.929 \\
\hline Diseases of the respiratory system (RSD) & Sprue & 16 & 4 & 0.800 \\
\hline Diseases of the skin and subcutaneous & Itch, swelling & 44 & 3 & 0.953 \\
\hline Endocrine, nutritional and metabolic disec & Diabetes & 35 & 6 & 0.853 \\
\hline Mental and behavioral disorders (MBD) & a, laxative & 15 & 2 & 0.929 \\
\hline ory and respiratory systems (DCR) & Cous & 65 & 4 & 0.953 \\
\hline Symptoms, signs, and abnormal clinical a & Fever, cold & 183 & 11 & 0.945 \\
\hline Diseases of the musculoskeletal system and connective tissue (DMC) & Gout arthritis & 31 & 7 & 0.800 \\
\hline Symptoms and signs involving the skin and subcutaneous tissue (SCT) & Skin burn & 9 & 2 & 0.875 \\
\hline Diseases of the skin and subcutaneous tissue (DST) & Alopecia & 19 & 2 & 0.944 \\
\hline Neoplasms (NP) & Breast cancer & 4 & 2 & 0.667 \\
\hline Injury, poisoning, and certain other consequences of external causes (IPD) & Wound & 65 & 5 & 0.938 \\
\hline
\end{tabular}

Note: International Classification of Diseases - 10 ver. 2019 (https://icd.who.int)

Traditional knowledge of medicinal plants has been passed down through communities from generation to generation. The average number of species identified by each age group of the respondent ranged from $8.11 \pm 1.21$ $(15-25$ years) to $62.31 \pm 1.12$ (> 65 years). The statistical analysis revealed a significant difference in traditional knowledge of medicinal plants between the elders and the younger generation $(\mathrm{P}<0.05 ; \mathrm{n}=60)$. This suggests that traditional knowledge is eroding across generations. This study supports the findings of Sujarwo et al. (2014) and Weckmüller et al. (2019), who discovered that elders have greater medicinal plant knowledge than younger generations. During the survey, we discovered that the younger generation is less interested in traditional medical systems. They prefer to consume modern medicine, which is widely available in the pharmacy/drugstore. The young generation, particularly those between the ages of 15 and 25, are known as millennials, and they have strong relationships with information exchange, media, and digital technology, in particular the internet and smartphones. They prefer to get immediate health information from online health platforms. As a result, the young generation prefers modern medicine systems over traditional medicine systems, assuming that modern medicine is perceived to be easier and more practical. According to Sujarwo et al. (2014), the use of the internet/smartphones has contributed to cultural erosion among younger generations, particularly those related to indigenous knowledge of nutraceutical plants. The village government and elders have provided various initiatives to protect traditional knowledge related to traditional medicine systems. The village government has begun to establish traditional medicine gardens in their village in order to promote and conserve the traditional medicine system. Moreover, elders, particularly mothers, have passed on knowledge of plants as a traditional medicine to their children, though this practice remains limited. Since traditional medicinal knowledge is passed down orally from generation to generation, basic knowledge could be lost.

Overall, the large number of medicinal plants mentioned by local communities demonstrated important local knowledge in the study area. The findings revealed that 46 medicinal plant species from 40 genera and 26 families were used for medicinal purposes by local communities to treat 28 different diseases with the itch, swelling, cough, and nose bleeding being the most commonly treated. With a use-value index of 0.98 , Tagetes erecta was the most commonly used medicinal plant by local communities. Local communities identified the leaf $(50 \%)$ as the most widely used plant part and oral administration $(65 \%)$ as the most common method of administering traditional medicine. Initiatives to promote and conserve medicinal plants, however, must be improved, particularly among the younger generation. This is required to ensure the availability of medicinal plants and the preservation of traditional knowledge in the future.

\section{ACKNOWLEDGEMENTS}

We are grateful to all people in the studied villages for their kind hospitality and share of knowledge. We also want to express our gratitude to Samudra University for supporting this study with a basic research grant in the year 2021 .

\section{REFERENCES}

Ani N, Sukenti K, Aryanti E, Rohyani IS. 2021. Ethnobotany study of medicinal plants by the Mbojo Tribe Community in Ndano Village at the Madapangga Nature Park, Bima, West Nusa Tenggara. Jurnal Biologi Tropis 21 (2): 456-469. DOI: 10.29303/jbt.v21i2.2666. [Indonesian]. Aziz M, Adnan M, Khan A, Shahat A, Al-Said M, Ullah R. 2018. Traditional uses of medicinal plants practiced by the indigenous communities at Mohmand agency, FATA, Pakistan. J Ethnobiol Ethnomed 14 (2): 2-16. DOI: 10.1186/s13002-017-0204-5 
Bano A, Ahmad M, Hadda TB, Saboor A, Sultana S, Zafar M, Khan MPZ, Arshad M, Ashraf MA. 2014. Quantitative ethnomedicinal study of plants used in the skardu valley at high altitude of Karakoram-Himalayan range, Pakistan. J Ethnobiol Ethnomed 10 (1): 43. DOI: 10.1186/1746-4269-10-43

Bruschi P, Sugni M, Moretti A, Signorini MA, Fico G. 2019. Children's versus adult's knowledge of medicinal plants: An ethnobotanica study in Tremezzina (Como, Lombardy, Italy). Revista Brasileira de Farmacognosia 29 (5): 644-655. DOI: 10.1016/j.bjp.2019.04.009

Elfrida, Mubarak A, Suwardi AB. 2020. The fruit plant species diversity in the home gardens and their contribution to the livelihood of communities in rural area. Biodiversitas 21 (8): 3670-3675. DOI: 10.13057/biodiv/d210833

Elfrida E, Tarigan NS, Suwardi AB. 2021. Ethnobotanical study of medicinal plants used by community in Jambur Labu Village, East Aceh, Indonesia. Biodiversitas 22 (7): 2893-2900. DOI: 10.13057/biodiv/d220741

Endale A, Bisrat D, Animut A, Bucar F, Asres K. 2013. In vivo antimalarial activity of a labdane diterpenoid from the leaves of Otostegia integrifolia Benth. Phytother Res 27 (12): 1805-1809. DOI: 10.1002/ptr.4948

Evert T, Vandebroek I, Sabino S, Van Damme P. 2009. Cultural significance of medicinal plant families and species among Quechua farmers in Apillapampa, Bolivia. J Ethnopharmacol 122: 60-67. DOI: 10.1016/j.jep.2008.11.021

Fuller CW, Prosser JD. 2018. Epistaxis in children: Evaluation and management. Curr Treat Options Peds 4: 203-210. DOI: 10.1007/s40746-018-0121-4

Heinrich M, Ankli A, Frei B, Weimann C, Sticher O. 1998. Medicinal plants in Mexico: Healers' consensus and cultural importance. Soc Sci Med 47 (11): 1859-1871. DOI: 10.1016/s0277-9536(98)00181-6

$\mathrm{Hu}$ R, Lin C, Xu W, Liu Y, Long C. 2020. Ethnobotanical study on medicinal plants used by Mulam people in Guangxi, China. J Ethnobiol Ethnomed 16: 40. DOI: 10.1186/s13002-020-00387-z

Ianni E, Geneletti D, Ciolli M. 2015. Revitalizing traditional ecological knowledge: a study in an alpine rural community. Environ Manag 56: 144-156. DOI: $10.1007 / \mathrm{s} 00267-015-0479-\mathrm{z}$

International Society of Ethnobiology. 2006. International Society of Ethnobiology Code of Ethics. http://www.ethnobiology.net

Ismail A, Wan Ahmad WAN. 2019. Syzygium polyanthum (Wight) Walp A potential phytomedicine. Pharmacogn J 11 (2): 429-438. DOI: 10.5530/pj.2019.11.67

Jadid N, Kurniawan E, Himayani CES, Andriyani, Prasetyowati I, Purwani KI, Muslihatin W, Hidayati D, Tjahjaningrum ITD. 2020. An ethnobotanical study of medicinal plants used by the Tengger tribe in Ngadisari village, Indonesia. PLoS ONE 15 (7): 1-16. DOI: 10.1371 /journal.pone. 0235886

Kidane L, Gebremedhin G, Beyene T. 2018. Ethnobotanical study of medicina plants in Ganta Afeshum District, Eastern Zone of Tigray, Northern Ethiopia. J Ethnobiol Ethnomed 14: 64. DOI: 10.1186/s13002-018-0266-Z

Luo BS, Liu YJ, Liu B, Liu SZ, Zhang BX, Zhang LH, Lin CR, Liu Y, Kennelly EJ, Guo ZY, Long CL. 2018. Yao herbal medicinal market during the Dragon Boat Festival in Jianghua County, China. J Ethnobiol Ethnomed 14: 61. DOI: 10.1186/s13002-018-0260-5

Merétika AHC, Peroni N, Hanazaki N. 2010. Local knowledge of medicinal plants in three artisanal fishing communities (Itapoá Southern Brazil), according to gender, age, and urbanization. Acta Bot Brasilica 24: 386-394. DOI: 10.1590/S0102-33062010000200009

Miraldi E, Baini G. 2018. Medicinal plants and health in human history: From empirical use to modern phytotherapy. J Siena Acad Sci 10: 16. DOI: $10.4081 /$ jsas.2018.8529

Navia ZI, Suwardi AB, Harmawan T, Syamsuardi, Mukhtar E. 2020. The diversity and contribution of indigenous edible fruit plants to the rura community in the Gayo Highlands, Indonesia. J Agric Rural Dev Trop Subtrop 121 (1): 89-98. DOI: 10.17170/kobra-202004061145

Navia ZI, Suwardi AB, Nuraini. 2021. The importance of tropical edible fruit plants for tribal communities in East Aceh region, Indonesia. IOP Conf Ser Earth Environ Sci 637 (1): 012003. DOI: 10.1088/1755-1315/637/1/012003

Nzuki BF, Céline C, Kibungu KAO, Van Damme P. 2013. Identification et importance locale des plantes médicinales utilisées dans la région de Mbanza-Ngungu, République démocratique du Congo. Bois et Forets des Tropiques 67 (316): 63-77. DOI: 10.19182/bft2013.316.a20531

Pathy KK, Flavien NB, Honoré BK, Vanhove W, Van Damme P. 2021 Ethnobotanical characterization of medicinal plants used in Kisantu and Mbanza-Ngungu territories, Kongo-Central Province in DR Congo. J Ethnobiol Ethnomed 17: 5. DOI: 10.1186/s13002-020-00428-7
Phumthum M, Srithi K, Inta A, Junsongduang A, Tangjitman K, Pongamornkul W, Trisonthi C, Balslev H. 2018. Ethnomedicinal plant diversity in Thailand. J Ethnopharmacol 214: 90-98. DOI: 10.1016/j.jep. 2017.12.003

Pimenta LPS, Garcia GM, Gonçalves SGDV, Dionísio BL, Braga ÉM, Mosqueira VCF. 2014. In vivo antimalarial efficacy of acetogenins, alkaloids and flavonoids enriched fractions from Annona crassiflora Mart. Nat Prod Res 28 (16): 1254-1259. DOI: 10.1080/14786419.2014.900496

Polat R, Cakilcioglu U, Kaltalioglu K, Ulusan MD, Tuurkmen Z. 2015. An ethnobotanical study on medicinal plants in Espiye and its surrounding (Giresun-Turkey). J Ethnopharmacol 163: 1-11. DOI: 10.1016/j. jep.2015.01.008

Said HS, Mohasseb MM. 2020. Epistaxis among children in Lower Egypt: Frequency and risk factors. Egypt Fam Med J 4 (2): 51-63. DOI: 10.21608/efmj.2020.19820.1001

Shah SK, Garg G, Jhade D, Patel N. 2016. Piper betle: Phytochemical, pharmacological and nutritional value in health management. Intl $\mathrm{J}$ Pharm Sci Rev Res 38 (2): 181-189.

Somsak V, Polwiang N, Chachiyo S. 2016. In vivo antimalarial activity of Annona muricata leaf extract in mice infected with Plasmodium berghei. J Pathog 2016: 1-5. DOI: 10.1155/2016/3264070

Sucipto TH, Aisyah N, Lestari P, Setyawati H. 2016. Betle leaf essential oil for hemophiliac patients and its antibacterial effects on Mycobacterium tuberculosis. Indones J Trop Infect Dis 6 (3): 63-67. DOI: $10.20473 /$ ijtid.v6i3.1387

Sujarwo W, Arinasa IBK, Salomone F, Caneva I, Fattorini S. 2014. Cultural erosion of balinese indigenous knowledge of food and nutraceutical plants. Econ Bot 68 (4): 426-437. DOI: 10.1007/s12231014-9288-1

Sutrisno IH, Bachtiar A, Navia ZI, Nuraini, Suwardi AB. 2020. Documentation of ritual plants used among the Aceh tribe in Peureulak, East Aceh District, Indonesia. Biodiversitas 21 (22): 49904998. DOI: $10.13057 /$ biodiv/d211102

Sutrisno IH, Suwardi AB, Navia ZI, Baihaqi B, Fadhilah MA. 2021. Documentation of the traditional Alas food in Southeast Aceh District, Indonesia. Biodiversitas 22 (8): 3243-3249. DOI: 10.13057/biodiv/d220818

Suwardi AB, Navia ZI, Harmawan T, Syamsuardi, Mukhtar E. 2020. Wild edible fruits generate substantial income for local people of the Gunung Leuser National Park, Aceh Tamiang region. Ethnobot Res Appl 20: 1-13. DOI: 10.32859/era.20.11.1-13

Suwardi AB, Mardudi, Navia ZI, Baihaqi, Muntaha. 2021. Documentation of medicinal plants used by Aneuk Jamee tribe in Kota Bahagia Subdistrict, South Aceh, Indonesia. Biodiversitas 22 (1): 2085-4722. DOI: $10.13057 /$ biodiv/d220102

Tantengco OA, Condes MA, Estadilla HH, Ragragio EM. 2018. Ethnobotanical survey of medicinal plants used by Ayta communities in Dinalupihan, Bataan, Philippines. Pharmacog J 10 (5): 859-870. DOI: $10.5530 / \mathrm{pj} .2018 .5 .145$

The Central Bureau of Statistics of Aceh Tamiang District. 2021. Sekerak Subdistrict in Figure 2021. The Central Bureau of Statistics of Aceh Tamiang District, Indonesia.

Tugume P, Nyakoojo C. 2019. Ethno-pharmacological survey of herbal remedies used in the treatment of paediatric diseases in Buhunga parish, Rukungiri District, Uganda. BMC Complement Altern Med 19: 353. DOI: $10.1186 / \mathrm{s} 12906-019-2763-6$

Ugulu I. 2010. Fidelity level and knowledge of medicinal plants used to make therapeutic Turkish baths. J Altern Complement Med 16 (3): 313-322. DOI: 10.1089/acm.2009.0040.

Qureshi R, Ghazanfar SA, Obied H, Vasileva, Tariq MA. 2016. Ethnobotany: A living science for alleviating human suffering. Evidence-Based Complement Altern Med 2016: 1-3. DOI: 10.1155/2016/9641692

Rivera D, Obon C, Inocencio C, Heinrich M, Verde A, Fajardo J, Llorach R. 2005. The ethnobotanical study of local Mediterranean food plants as medicinal resources in Southern Spain. J Physiol Pharm 56: 97-114.

Wang J, Zhu M, Xiang L, Xiao Y. 2002. Chinese medicinal bath for Psoriasis vulgaris. J Chin Phys 4: 96-7.

Weckmüller H, Barriocanal C, Maneja R, Boada M. 2019. Factors affecting traditional medicinal plant knowledge of the Waorani, Ecuador. Sustainability 11: 4460. DOI:10.3390/su11164460

Yang C, Long CL, Shi Y, Wang Y, Wang H. 2009. Ethnobotanical study on medicinal market during Dragon Boat Festival in Jingxi County, southwestern Guangxi region. J CUN (Nat Sci Ed) 18 (2): 16-26.

Yineger H, Yewhalaw D, Teketay D. 2008. Ethnomedicinal plant knowledge and practice of the Oromo ethnic group in southwestern Ethiopia. J Ethnobiol Ethnomed 4: 11. DOI: 10.1186/1746-4269-4-11 